\title{
ПЕТИ ФОРУМ „БЪЛГАРСКА ГРАМАТИКА“
}

През 2018 година Институтьт за български език „Проф. Л. Андрейчин“ вече по традиция (за пети пореден път) организира Форума „Българска граматика“.

Форматът на Форума включва съвместна организация с някой от водещите университети в България, където се провеждат езиковедски изследвания. През 2018 година организатори бяха Шуменският университет „Епископ Константин Преславски“ и Институтьт за български език „Проф. Л. Андрейчин“" при Българската академия на науките.

Форумът се състоя на 18 и 19 октомври 2018 г. - за първи път в рамките на два дни. Интересната тема на Форума: „Динамика на синтактичните идеи на границата на две столетия“, беше предложена от езиковедите от Шуменския университет „Епископ Константин Преславски“ и събра над 100 езиковеди от България и извън страната, които се срещнаха в Института за български език „Проф. Л. Андрейчин“ и обмениха информация за нови постижения и идеи, свързани с българския синтаксис в контекста на развитието на синтактичната теория.

Бяха разгледани проблеми, свързани с описаниетона синтактични структури в българския език и изследванията на съвременните синтактични теории. Дискусията беше съсредоточена около следните основни въпроси:

- Какви са задачите, предизвикателствата и очакваните резултати от модерния синтаксис?

- Къде е границата между традиционния и модерния синтаксис и при какви случаи следва единият да се предпочете вместо другия?

Фокусът на докладите и дискусиите беше предимно върху синтактична проблематика, но наред с това бяха засегнати морфологични и семантични въпроси, свързани със синтаксиса.

Основни доклади на форума изнесоха проф. Ивелина Савова (Шуменски университет „Епископ Константин Преславски“): Синтаксис и хиперсинтаксис; проф. Елена Иванова (Санктпетербургски държавен университет): Граматични категории в структурата на подчиненото изречение: контекстово изместване и реинтерпретация в български; проф. Светла Коева (Институт за български език „Проф. Любомир Андрейчин“): Tuпология на (рестриктивните и нерестриктивните) подчинени изречения в 
български; проф. Йовка Тишева (Софийски университет „Св. Климент Охридски“): Означаване на синтактични отночения в простото изречение: предложни и именни фрази; проф. Мила Вълчанова и проф. Валентин Вълчанов (Норвежки университет за наука и технологии): Лексикална семантика и граматика: теоретични и емпирични перспективи. Сред останалите доклади се откроиха докладите на проф. Петя Осенова (Софийски университет „Св. Климент Охридски“): Явни и неявни връзки при моделиране на синтактичните отношения; проф. Велка Попова (Шуменски университет „Епископ Константин Преславски“): Синтактични иновации в българския детски език; проф. Радка Влахова (Софийски университет „Св. Климент Охридски“): Задпоставените определения - някои семантични и синтактични въпроси; доц. Петя Бъркалова (Пловдивски университет „Паисий Хилендарски“): Българската синтактична традиция и синтактичният анализ през 21. век; доц. Марина Джонова (Софийски университет „Св. Климент Охридски“): Удвояване на релативите в българския език; доц. Галина Петрова (Университет „Проф. д-р Асен Златаров“"): Подчинени определителни да-изречения в българския език: хабитуално и модално значение; доц. Димитрина Лесневска (Университет за национално и световно стопанство): Синтактични особености на българските и руските делови писма (в съпоставителен план). Имаше и доклади, които запознаха аудиторията със синтактични теории, изпреварили времето си, или нови синтактични теории: докладите на доц. Петя Несторова (Университет за хранителни технологии): Една модерна теория в българския синтаксис на границата на две столетия, и на гл. ас. Елисавета Балабанова (Университет по библиотекознание и информационни технологии): Синтаксис на адюнктите на Томас Ернст - една лингвистична теория от 21. век. В следобедното заседание на 18 октомври доклади изнесоха и млади изследователи: Димитьр Георгиев (Пловдивски университет „Паисий Хилендарски“): Формални описания на сложни съставни изречения с подчинени подложни в прикопулна позииия; ас. Станислава Теофилова (Шуменски университет „Епископ Константин Преславски“): Някои наблюдения върху словореда на комбиначията от съгласувано и несъгласувано определение в рамките на съобщителното изказване (върху материал от българската разговорна реч).

Форумът „Динамика на синтактичните идеи на границата на две столетия“ беше най-подходящото събитие за представянето на сборника „Доклади от Юбилейната научна сесия „Съвременни тенденции в езиковедските изследвания, посветена на 85 години от рождението на проф. д.ф.н. Йордан Пенчев“. Участниците във Форума получиха екземпляри от книгата от Института за български език „Проф. Л. Андрейчин“.

За първи път на петото издание на Форума беше представена и изложба. На изложбата „Синтактични дървета - картини на мисълта“, организирана от Пловдивския университет „Паисий Хилендарски“ и Института за 
български език „Проф. Л. Андрейчин“, бяха представени синтактични структури, разработени от студенти и докторанти в Пловдивския университет „Паисий Хилендарски“ и в Софийския университет „Св. Климент Охридски“").

В Приложението на сп. „Български език“ през 2019 г. читателите ще имат възможност да се запознаят с докладите на проф. Ивелина Савова от Шуменския университет „Епископ Константин Преславски“, проф. Елена Иванова от Санктпетербургския държавен университет, проф. Светла Коева от Института за български език „Проф. Любомир Андрейчин“, проф. Йовка Тишева от Софийския университет „Св. Климент Охридски“, проф. Петя Осенова от Софийския университет „Св. Климент Охридски“, проф. Велка Попова от Шуменския университет „Епископ Константин Преславски“, проф. Радка Влахова от Софийския университет „Св. Климент Охридски“, доц. Марина Джонова от Софийския университет „Св. Климент Охридски“, доц. Димитрина Лесневска от Университета за национално и световно стопанство, доц. Петя Несторова от Университета за хранителни технологии и гл. ас. Елисавета Балабанова от Университета по библиотекознание и информационни технологии.

Петото издание на Форума „Българска граматика“ напълно постигна своите цели: не (само) да се предлагат решения и да се представят постижения, но и да се обменят мнения и да се създаде среда за непосредствен разговор за мястото на синтаксиса в езиковедските изследвания.

През октомври 2019 година ще се състои шестото издание на Форума „Българска граматика“ на тема „Граматичните системи в синхрония и диахрония“, което се организира от Югозападния университет „Неофит Рилски“ и Института за български език „Проф. Л. Андрейчин“ при Българската академия на науките.

СветЛА КОевА

ИНСТИТУТ ЗА БЪЛГАРСКИ ЕЗИК „ПРОФ. Л. АНДРЕЙЧИН““ ПРИ БАН svetla@dcl.bas.bg

Публикувано: 3 октомври 2019 